\title{
Emergence of a Novel Population of Puccinia striiformis f. sp. tritici in Eastern United States
}

\author{
S. G. Markell and E. A. Milus \\ First author: Department of Plant Pathology, North Dakota State University, Fargo 58105-5012; and second author: Department of Plant \\ Pathology, University of Arkansas, Fayetteville 72701. \\ Accepted for publication 31 January 2008.
}

\section{ABSTRACT}

Markell, S. G., and Milus, E. A. 2008. Emergence of a novel population of Puccinia striiformis f. sp. tritici in eastern United States. Phytopathology 98:632-639.

The geographic range of stripe rust of wheat, caused by Puccinia striiformis f. sp. tritici, has increased dramatically since 2000 in the United States. Yield losses to the disease have been most severe in the eastern United States, where measurable yield loss had been rare prior to 2000 . The objective of this study was to examine the phenotypic and genotypic variation among isolates of $P$. striiformis $\mathrm{f}$. sp. tritici collected from populations in the eastern United States before and since 2000. Virulence phenotype and amplified fragment length polymorphism (AFLP) markers were used to examine 42 isolates collected between 1960 and 2004. In addition, the genetic structure of 59 isolates collected in 2005 using a hierarchical sampling strategy was examined. The data indicated that the contemporary isolates (collected since 2000) were very distinct from older isolates (collected before 2000) based on virulence and AFLP markers, and that the old population prevalent before 2000 may have been replaced by the contemporary population. The old and new populations appear to be genetically distinct and may represent an exotic introduction rather than a mutation in isolates of the old population.

Additional keywords: population structure, Triticum aestivum, yellow rust.
Stripe rust, caused by Puccinia striiformis Westend. f. sp. tritici Eriks., is an economically important wheat disease on all continents where wheat is grown. In the United States, stripe rust historically has been a severe problem in the Pacific Northwest and California, but occurred infrequently in states east of the Rocky Mountains and rarely caused severe losses (18). Before 2000 , only four of the 59 described races of the pathogen were recovered east of the Rocky Mountains, all new races were first found in western United States, and all known races in the United States were avirulent on resistance genes $\operatorname{Yr} 8$ and $\operatorname{Yr} 9$ (6).

In 2000, stripe rust occurred in at least 20 states from the Pacific Northwest and California to Virginia and from Texas to North Dakota (6). This was the most widespread and severe stripe rust epidemic in the United States, and unlike previous epidemics, it was most severe in Arkansas, Louisiana, and Texas (3). Isolates of the pathogen had virulence on resistance genes $\operatorname{Yr} 8, \operatorname{Yr} 9$, and the unknown resistance in the cultivar Express. The $\operatorname{Yr} 9$ resistance gene is carried on the 1BL.1RS translocation that is common in soft and hard red wheat cultivars grown in the United States (3), and the new population was able to cause infection on several cultivars that had been resistant. Therefore, virulence to $\operatorname{Yr} 9$ confers an advantage to the pathogen east of the Rocky Mountains. However, $\operatorname{Yr} 8$ and the resistance in Express are not known to be in any cultivars grown in the region.

Since 2000, severe stripe rust epidemics have frequently occurred in states east of the Rocky Mountains and have been most severe in the south-central United States (Arkansas, Louisiana, Kansas, Oklahoma, and Texas) (3). Annual race surveys demonstrated that new races identified since 2000 are now predominant throughout the eastern United States (3), indicating that the new population has greater fitness than the old

Corresponding author: S. G. Markell; E-mail address: samuel.markell@ndsu.edu

doi:10.1094/PHYTO-98-6-0632

(C) 2008 The American Phytopathological Society population. Milus et al. (20) found that isolates collected since 2000 had shorter latent periods and faster spore germination at warmer temperatures than isolates collected before 2000, indicating that the new population is more fit than the old population at warmer temperatures. The differences in virulence, fitness, and aggressiveness among isolates collected before 2000, suggest that the contemporary $P$. striiformis f. sp. tritici population in eastern United States is different from the population that existed before 2000.

In the United States, most information about diversity of $P$. striiformis f. sp. tritici is based on virulence (15). Virulence is based on a few loci that are under intense selection pressure by resistance genes deployed in cultivars (22), but can be useful for determining genetic diversity of asexual rusts. Genetic diversity information generated with molecular markers of $P$. striiformis $\mathrm{f}$. sp. tritici in the United States is limited, and no information is available since 2000. In 1993, Chen et al. (4) reported little genetic diversity among 115 isolates with random amplified polymorphic DNA (RAPD) markers, and while virulence data correlated to geographic region, data generated with RAPD markers did not (4). In 1995, Chen et al. (5) reported genetic diversity among seven isolates of $P$. striiformis $\mathrm{f}$. sp. tritici and between isolates of numerous other Puccinia species including P. striiformis f. sp hordei and $P$. striiformis f. sp. poae using RAPD markers. Several molecular techniques have been used to elucidate diversity of $P$. striiformis $\mathrm{f}$. sp. tritici in other regions of the world. Shan et al. (23) found a high level of genetic variation among 160 Chinese isolates using a moderately repetitive DNA sequence as a probe. However, $20 \mathrm{mg}$ of urediniospores per sample were required for DNA extraction making a polymerase chain reaction (PCR) based technique more desirable. Steele et al. (24) found no polymorphisms among Australian isolates using RAPD and amplified fragment linked polymorphism (AFLP) techniques. However, when isolates from the United Kingdom and Denmark were included in the analysis, approximately $3 \%$ of RAPD bands were polymorphic, and an average of 6.5 poly- 
morphisms per AFLP primer combination were identified. Justesen et al. (12) identified 21 AFLP primer pair combinations that revealed 16 phenotypes among 76 Danish isolates. Using the same AFLP primer combinations, Hovmoller et al. (10) demonstrated that long distance migration of $P$. striiformis f. sp. tritici occurred throughout Northwestern Europe. Using 15 of those AFLP primer combinations, Enjalbert et al. (9) identified two distinct $P$. striiformis f. sp. tritici populations among 213 French isolates. Furthermore, 40 of the 60 scored polymorphisms were specific to the $6 \mathrm{E} 16$ pathotype (the only observed race with virulence to $\mathrm{Yr} 8$ ) that was recovered almost exclusively in southern France, while the other pathotypes belonged to the Northwest European group (9). Using microsatellite primers or simple sequence repeats (SSR), Enjalbert et al. (8) were able to separate isolates of the 6E16 pathotype from other European pathotypes and to distinguish them from two groups of Chinese isolates.

While population diversity can be analyzed using random samples from a pathogen population (e.g., annual race surveys), hierarchical sampling strategies provide a better understanding of the genetic structure of the population (19). Hierarchical sampling has been used to assess genetic structure of several cereal pathogens, including Mycosphaerella graminicola (14), Rhynchosporium secalis (19), and Stagonospora nodorum (13). Although hierarchical sampling may be most useful for splash dispersed or seedborne pathogens, hierarchical analysis could be useful if diversity is found among co-existing populations. Villareal et al. (25) sampled a defined number of $P$. strifformis $\mathrm{f}$. sp. tritici isolates at 10 defined locations along transects of wheat fields in northern France and used these and other samples to demonstrate that the population in northern France was clonal at the field level.

The objective of this study was to examine the genetic and virulence diversity of populations of $P$. striiformis f. sp. tritici in the eastern United States before and since 2000.

\section{MATERIALS AND METHODS}

Isolates. Because only two isolates (AR90-01 and AR97-01) from eastern United States before 2000 were available for this study, 12 isolates from western United States were obtained from X. M. Chen, and nine isolates from Montana were obtained from M. Johnston to represent the pre-2000 pathogen population (Table 1). All Montana isolates were obtained in vials sealed in the year collected, verifying that they represented isolates from this period. Single-lesion isolates were later derived in Arkansas from four field collections. To ensure genetic purity, all isolates except three of the field collections from Montana (MT82, MT81, and MT87) were derived from single-lesion transfers.

Isolates representative of the population since 2000 included 21 isolates from Alabama, Arkansas, Kansas, Louisiana, and Oklahoma collected between 2000 and 2004 (Table 1). Isolates collected in 2000 and 2001 were obtained from X. M. Chen and derived from single-lesions in Arkansas. All isolates collected since 2002 were single-lesion isolates. A leaf with a single stripe of uredia was detached from a plant in the field, placed on benzimidazole agar $(0.012 \mathrm{~g}$ of benzimidazole, $1.7 \mathrm{~g}$ of agar, and $400 \mathrm{ml}$ of water) in a petri plate, and incubated in a growth chamber at $15^{\circ} \mathrm{C} / 10^{\circ} \mathrm{C}$ (day/night) with a 14 -h photoperiod. Spores were collected multiple times using a small vacuum spore collector.

To increase urediniospores of each $P$. striiformis $\mathrm{f}$. $\mathrm{sp}$. tritici isolate, six $8-\mathrm{cm}$ pots with 20 to 2510 -day-old wheat seedlings (cv. Florida 302 and Agripro Hickory) were inoculated with a suspension of urediniospores in Soltrol 170 mineral oil. After the oil evaporated, plants were placed in a dew chamber at $12^{\circ} \mathrm{C}$ for $24 \mathrm{~h}$ and then incubated in a growth chamber at $15^{\circ} \mathrm{C} / 10^{\circ} \mathrm{C}$ (day/ night) with a 14-h photoperiod. To minimize cross contamination, plants were isolated in plexiglass booths or glassine bags (Model S-11592, ULine, Waukegan, IL). Spores were harvested using vacuum spore collectors or by tapping spores off wheat leaves onto the side of the glassine bags. Spores were dried in desiccators at $4^{\circ} \mathrm{C}$ for $48 \mathrm{~h}$ before being used for inoculation, DNA extraction, or being transferred to long-term storage at $-80^{\circ} \mathrm{C}$.

Virulence. For all isolates, virulence phenotype (race) was determined on the United States standard set of 20 differentials (6). Two replicates of each differential set were inoculated with urediniospores as described previously. After a 24-h dew period at $12^{\circ} \mathrm{C}$, plants were incubated in a growth chamber programmed to gradually change from 18 to $8^{\circ} \mathrm{C}$ between 6:00 p.m. and midnight, remain at $8^{\circ} \mathrm{C}$ until 6:00 a.m., gradually change from 8 to $18^{\circ} \mathrm{C}$ between 6:00 a.m. and noon, and remain at $18^{\circ} \mathrm{C}$ until 6:00 p.m. Growth chambers had a 14-h photoperiod (6:00 a.m. to 8:00 p.m.). Virulence phenotypes were characterized on first and second leaves 14 to 15 days after inoculation on a 0 to 9 scale (18) according to Chen et al. (6), where infection types 0 to 4 were considered avirulent and infection types 5 to 9 were considered virulent. If an isolate differed for infection type (avirulent or virulent) on any differential lines in the two replicates or an isolate was phenotyped as an unknown race, these isolates were retested on the differential lines in question.

AFLP analysis. With few exceptions, 0.5 to $10 \mathrm{mg}$ of desiccated urediniospores were combined with $2 \mathrm{~g}$ of $0.7-\mathrm{mm}$ zirconia beads, one $2.3-\mathrm{mm}$ stainless steel bead, one 3.2-mm stainless steel bead (Biospec Products Inc., Bartlesville, OK) and $1.3 \mathrm{ml}$ DNA extraction buffer $(65 \mathrm{ml}$ of sterile deionized water, $5 \mathrm{ml}$ of $5 \mathrm{M}$ $\mathrm{NaCl}, 5 \mathrm{ml}$ of $0.5 \mathrm{M}$ EDTA, $5 \mathrm{ml}$ of $10 \% \mathrm{SDS}$, and $20 \mathrm{ml}$ of $1 \mathrm{M}$ Tris, $\mathrm{pH}$ 8.0) in a 2-ml centrifuge tube. The centrifuge tube was shaken twice for $30 \mathrm{~s}$ in a Silamat S3 Amalgamator (Vivadent, Schaan, Liechtenstein). DNA was extracted using a modified CTAB procedure (21) according to Irish (11), and quantitated to $50 \mathrm{ng} / \mu \mathrm{l}$ using an ND-1000 spectrophotometer (Nanodrop Technologies, Wilmington, DE).

AFLP procedures were performed according to the following as described by Vos et al. (26). The 21 selective primer pairs identified by Justesen et al. (12) and one additional selective primer pair, P26(TT)/M14(AT) (A. Justesen, personal communication), were used to analyze 6 isolates collected before 2000 (PST-21, PST-29, PST-43, PST-6-3, AR97-01sp2, and AR90-01sp1) and 10 isolates collected since 2000 (AR03-01, AR03-04, AR03-14, AR03-25, AR03-33, AR00-00sp1, AR00-05sp1, LA04-16, 01-69, and AR05-IIA-1). All AFLP reactions were performed in a PTC2000 Thermol Cycler (MJ Research Inc., Watertown, MA). Enzymes and buffers from New England Biolabs (Ipswich, MA) were used for restriction digest and adaptor ligation steps. For restriction digest, $4 \mu \mathrm{l}$ of DNA $(75 \mathrm{ng} / \mu \mathrm{l}), 2.5 \mu \mathrm{l}$ of $10 \times$ buffer 2 , $2.5 \mu \mathrm{l}$ of $10 \times \mathrm{BSA}, 0.5 \mu \mathrm{l}$ of $\mathrm{Mse} \mathrm{I}(10 \mathrm{U} / \mu \mathrm{l}), 0.25 \mu \mathrm{l}$ of Pst $(20 \mathrm{U} / \mu \mathrm{l})$, and $15.25 \mu \mathrm{l}$ of sterile $\mathrm{ddH}_{2} \mathrm{O}$ were incubated at $37^{\circ} \mathrm{C}$ for $3 \mathrm{~h}$. For ligation, $2.5 \mu \mathrm{l}$ of ligation buffer, $1 \mu \mathrm{l}$ of T4 DNA ligase, $2 \mu \mathrm{l}$ of $P s t \mathrm{I}$ adaptor $(5 \mathrm{pmol} / \mu \mathrm{l}), 2 \mu \mathrm{l}$ of $M s e \mathrm{I}$ adaptor (50 pmol/ $\mu \mathrm{l}$ ), and $17.5 \mu \mathrm{l}$ of sterile $\mathrm{ddH}_{2} \mathrm{O}$ were added to restriction digest and incubated overnight at $16^{\circ} \mathrm{C}$. Restrictionligation solution was diluted 1:10 in TE buffer $(10 \mathrm{mM}$ Tris- $\mathrm{HCl}$ and $1 \mathrm{mM}$ EDTA, pH 8.0) before the pre-amplification step. For pre-amplification, $5 \mu \mathrm{l}$ of diluted restriction-ligation solution, $4 \mu \mathrm{l}$ of each preselective primer $(50 \mathrm{pmol} / \mu \mathrm{l})$, and $12 \mu \mathrm{l}$ of $\mathrm{ddH}_{2} \mathrm{O}$ were mixed with PuReTaq Ready-To-Go PCR Beads (GE healthcare Ltd., Buckinghamshire, UK) and were cycled for 20 cycles of $94^{\circ} \mathrm{C}$ for $30 \mathrm{~s}, 56^{\circ} \mathrm{C}$ for $30 \mathrm{~s}$, and $72^{\circ} \mathrm{C}$ for $60 \mathrm{~s}$. Pre-amplification products were diluted $1: 50$ in sterile $d_{d d H_{2}} \mathrm{O}$ before selective amplification. For the selective amplification step, all PstI selective primers were end labeled (5') with 6Fam fluorescent dye (Sigma Genosys, Houston, TX). For each selective amplification, $5 \mu \mathrm{l}$ of pre-amplified DNA, $4 \mu \mathrm{l}$ of each selective primer $(50 \mathrm{pmol} / \mu \mathrm{l})$, and $12 \mu \mathrm{l}$ of sterile $\mathrm{ddH}_{2} \mathrm{O}$ were mixed with PuReTaq Ready-To-Go PCR Beads and amplified according the following protocol: One cycle of $94^{\circ} \mathrm{C}$ for $30 \mathrm{~s}, 65^{\circ} \mathrm{C}$ for $30 \mathrm{~s}$, and $72^{\circ} \mathrm{C}$ for $60 \mathrm{~s}$ followed by 12 cycles of the same protocol with a 
$-0.7^{\circ} \mathrm{C}$ reduction in the middle step, and finally 23 cycles of $94^{\circ} \mathrm{C}$ for $30 \mathrm{~s}, 56^{\circ} \mathrm{C}$ for $30 \mathrm{~s}$, and $72^{\circ} \mathrm{C}$ for $60 \mathrm{~s}$.

For AFLP analysis, $1 \mu \mathrm{l}$ of amplified DNA was diluted in $10 \mu \mathrm{l}$ of Rox GS400HD size standard mix (50 $\mu$ l of Rox GS400HD and $950 \mu \mathrm{l}$ of formamide), denatured for $5 \mathrm{~min}$ at $95^{\circ} \mathrm{C}$, chilled on ice for $5 \mathrm{~min}$, and data were generated using Applied Biosystems Genetic Analyzer model 3100 (Foster City, CA). To analyze data, peak sizes below a relative fluorescent intensity (RFI) level of 100 were omitted to eliminate noise, bins were generated and manually edited, and peaks were scored as 0 (absent) or 1 (present) using GeneMapper 4.0 (Applied Biosystems, Foster City, CA). For each of the 22 primer pairs, at least 3 of the 16 isolates were repeated from the DNA extraction step and one blind control was included in each assay.
Based on the presence of informative and reproducible polymorphisms from the 16 United States isolates and DNA from four Danish isolates used only as controls for AFLP markers (data not shown), nine primer pairs (Table 2) were selected for analysis of an additional $85 P$. striiformis $\mathrm{f}$. sp. tritici isolates (Table 3). All AFLP procedures were done as described above. For every primer pair, all 16 of the original isolates were repeated from the DNA extraction step and one blind control was included in each analysis. Data from polymorphic markers were analyzed using the Numerical Taxonomy System for personal computers (NYTSISpc) (Setauket, NY). Cluster analysis of the similarity coefficients by unweighted pair group method with arithmetic mean (UPGMA) with the SAHN option was used to produce dendograms. Bootstrap values were calculated using the WinBoot

TABLE 1. Origin, year of collection, race, amplified fragment length polymorphism (AFLP) group, and virulence phenotype of Puccinia striiformis f. sp. tritici isolates used in this study

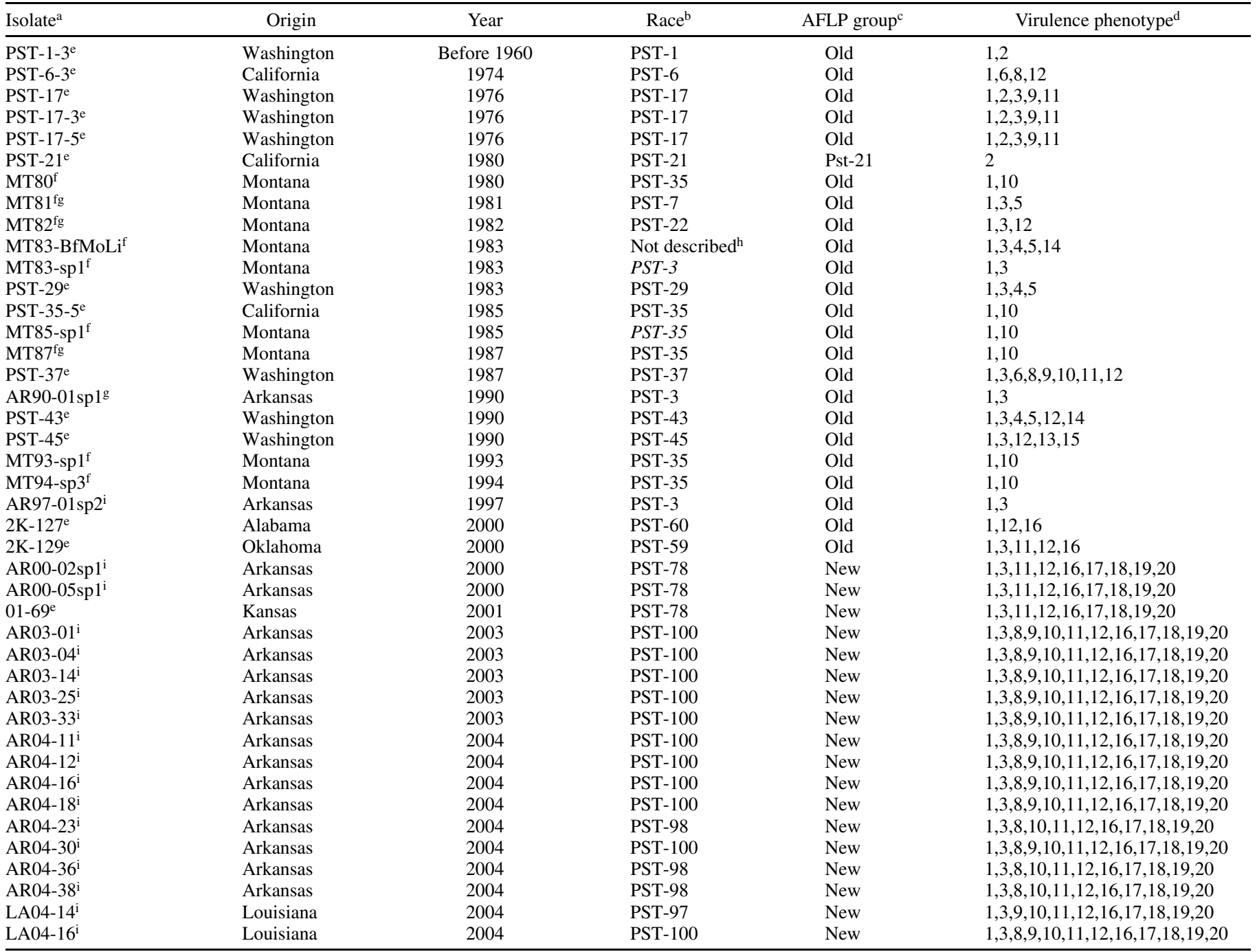

${ }^{a}$ All isolates except MT81, MT82, and MT87 were derived from single-lesion transfers. An isolate with a PST designation is the type culture for that race as determined by X. M. Chen.

${ }^{\mathrm{b}}$ Race was identified according to Chen et al. (6).

${ }^{c}$ Group refers to the AFLP cluster in which isolates were found (Figs. 1 and 2).

${ }^{\mathrm{d}}$ Host differentials with a virulent reaction (Infection type 5 to 9$)$ to isolate are listed. Differential number, name, and (genes): $1=\mathrm{Lemhi}(Y r 21), 2=\mathrm{Chinese} 166$ $(Y r 1), 3$ = Heines VII $(Y r 2, Y r H V I I), 4=$ Moro $(Y r 10, Y r M o r), 5=$ Paha $(Y r P a 1, Y r P a 2, Y r P a 3), 6=$ Druchamp $(Y r 3 a, Y r D r u 1, Y r D r u 2), 7=$ Avocet $Y r 5$ (Yr5), $8=$ Produra $(Y r P r 1, Y r P r 2), 9=$ Yamhill $(Y r 2, Y r 4 a, Y r Y a m), 10=$ Stephens $(Y r 3 a, Y r S t e 1, Y r S t e 2), 11=$ Lee $(Y r 7, Y r 22, Y r 23), 12=$ Fielder $(Y r 6, Y r 20), 13=$ Tyee $(Y r T y e), 14=$ Tres $(Y r T r 1, Y r T r 2), 15=$ Hyak $(Y r 17, Y r T y e), 16=$ Express $($ unkown $), 17=$ Avocet $Y r 8(Y r 8), 18=$ Avocet $Y r 9(Y r 9), 19=$ Clement $(Y r 9, \operatorname{YrCle})$, and $20=$ Compair $(\operatorname{Yr} 8, \operatorname{Yr} 19)$.

e Isolates were provided by X. M. Chen, United States Department of Agriculture, Agricultural Research Service, Pullman, WA.

${ }^{\mathrm{f}}$ Isolates were provided by M. Johnston, Montana State University, Bozeman, MT.

$\mathrm{g}$ Isolates were increased from a field collection.

${ }^{\mathrm{h}}$ Race has not been named.

${ }^{\mathrm{i}}$ Isolates were collected by the wheat pathology program at the University of Arkansas. 
software with the dice coefficient using 2000 iterations. The genetic variation among and within $P$. striiformis $\mathrm{f}$. sp. tritici populations was measured using Gst values according to Lowe et al. (17).

Hierarchical sampling. In 2005, hierarchical sampling was done in three regions of Arkansas: Crawford County in northwest Arkansas, Lafayette and Miller Counties in southwest Arkansas, and Lawrence County in northeast Arkansas. At least ten singlelesion isolates derived from an individual plant (plant-level of sampling) and an individual hot spot (area of collection within a 1 $\mathrm{m}^{2}$ area; hot spot-level of sampling), and ten bulk collections from a transect spanning more than $50 \%$ of the field length (transectlevel of sampling) were taken in two fields per region. A subset of 59 representative isolates (Table 3 ) were increased and analyzed as described previously. Five isolates each from one plant, one hot-spot, and one transect per region were randomly selected. Two additional isolates each from single plant and one or two hot-spots from the second field in each region were analyzed (Table 3). If differences were found, additional isolates from within the sampling level(s) could be increased and analyzed in the future. If any isolate did not grow, a randomly selected isolate from the same level of sampling in the same field was substituted. In one case (NW region, Transect-1) only four isolates grew (Table 3). A total of 59 hierarchically sampled isolates were analyzed.

\section{RESULTS}

Virulence. Of the 22 isolates representative of the United States population of $P$. striiformis $\mathrm{f}$. sp. tritici collected, 21 were identified as 1 of 12 races commonly found during this period (races PST-1, PST-3, PST-6, PST-7, PST-17, PST-21, PST-22, PST-29, PST-35, PST-37, PST-43, and PST-45) (Table 1). Isolate MT83-BfMoLi, collected in Montana in 1983, was virulent on differentials Lemhi, Heines VII, Moro, Paha, and Tres and avirulent on all other differentials. This virulence phenotype had not been reported previously. Annual race survey data demonstrated that virulence on differentials Lemhi, Moro, and Paha existed at the time of collection, but virulence on Tres was not recorded until 1989 (3). PST-21, an isolate recovered from California in 1980 , was only virulent on the differential Chinese 166. All isolates collected prior to 2000 were avirulent on Express, Avocet Yr8, Avocet $\operatorname{Yr} 9$, Clement, and Compair.

Twenty isolates collected since 2000 were determined to represent 6 races (PST-59, PST-60, PST-78, PST-97, PST-98, and PST100). PST-59 and PST-60 were virulent on the cultivar Express, but avirulent on differentials containing resistance genes $\mathrm{Yr} 8$, and Yr9. All other isolates collected since 2000 were virulent on Express, Avocet $Y r 8$, Avocet $Y r 9$, Clement, and Compair.

AFLP analysis. Two-hundred-nine polymorphisms were found when 22 AFLP primer-pair combinations were used to analyze 16 P. striiformis f. sp. tritici isolates from the United States (Table 2). Over $90 \%$ of these polymorphisms could be divided into three groups; specific to isolate PST-21 (87 polymorphisms), specific to isolates avirulent on differentials with resistance genes $\operatorname{Yr} 8$ and $\operatorname{Yr} 9$ (51 polymorphisms), and specific to isolates virulent on differentials with resistance genes $\mathrm{Yr} 8$ and $\mathrm{Yr} 9$ (59 polymorphisms). Only 12 polymorphisms differentiated isolates within one of the groups. Of these 209 polymorphisms, 107 were retained when the AFLP primer pair combinations were reduced to nine. When all 101 isolates used in this study (Tables 1 and 3) were analyzed with the nine selected primer pairs, 11 additional polymorphisms were identified. In summary, 43 polymorphisms were specific to PST-21, 27 polymorphisms were specific to isolates avirulent on $Y r 8$ and $Y r 9,34$ polymorphisms were specific to isolates virulent on $\operatorname{Yr} 8$ and $\operatorname{Yr} 9,4$ polymorphisms differentiated among isolates virulent to $\operatorname{Yr} 8$ and $\operatorname{Yr} 9,9$ polymorphisms differentiated among isolates avirulent to $\mathrm{Yr} 8$ and $\mathrm{Yr} 9$, and 1 polymorphism differentiated among isolates in both groups.

Cluster analysis of data generated from 22 primer-pair combinations on 16 isolates showed that isolates clustered into three distinct groups (Fig. 1). All isolates avirulent on $\operatorname{Yr} 8$ and $\operatorname{Yr} 9$

TABLE 2. Twenty-two amplified fragment length polymorphism (AFLP) primer combinations used in this study and the number of polymorphisms identified using 16 isolates of Puccinia striiformis f. sp. tritici $i^{\mathrm{a}}$

\begin{tabular}{|c|c|c|c|c|c|}
\hline \multirow[b]{2}{*}{ Primer combination $^{\mathrm{b}}$} & \multirow[b]{2}{*}{ Total } & \multicolumn{4}{|c|}{ Number of polymorphic markers } \\
\hline & & Specific for isolate PST-21 & $\begin{array}{c}\text { Specific for isolates } \\
\text { virulent on } \operatorname{Yr} 8 \text { and } \operatorname{Yr} 9\end{array}$ & $\begin{array}{c}\text { Specific for isolates } \\
\text { avirulent on } \operatorname{Yr} 8 \text { and } \operatorname{Yr} 9\end{array}$ & Not specific to one group \\
\hline $\mathrm{P} 11(\mathrm{AA}) / \mathrm{M} 16(\mathrm{CC})$ & 8 & 5 & 1 & 1 & 1 \\
\hline $\mathrm{P} 12(\mathrm{AC}) / \mathrm{M} 12(\mathrm{AC})$ & 10 & 6 & 2 & 2 & 0 \\
\hline $\mathrm{P} 12(\mathrm{AC}) / \mathrm{M} 13(\mathrm{AG})$ & 5 & 0 & 2 & 2 & 1 \\
\hline P13(AG)/M26(TT) & 7 & 2 & 4 & 1 & 0 \\
\hline P16(CC)/M14(AT) & 10 & 5 & 1 & 4 & 0 \\
\hline $\mathrm{P} 18(\mathrm{CT}) / \mathrm{M} 16(\mathrm{CC})$ & 5 & 1 & 0 & 3 & 1 \\
\hline P19(GA)/M22(GT) & 8 & 4 & 0 & 0 & 4 \\
\hline P19(GA)/M24(TC) & 11 & 5 & 2 & 4 & 0 \\
\hline P19(GA)/M25(TG) & 10 & 3 & 2 & 5 & 0 \\
\hline P20(GC)/M11(AA) & 9 & 3 & 2 & 4 & 0 \\
\hline P22(GT)/M22(GT) & 10 & 2 & 1 & 6 & 1 \\
\hline P22(GT)/M24(TC) & 12 & 8 & 2 & 1 & 1 \\
\hline P26(TT)/M14(AT) & 8 & 3 & 5 & 0 & 0 \\
\hline Sum & 209 & 87 & 51 & 59 & 12 \\
\hline
\end{tabular}

a Isolates = PST-21, PST-29, PST-43, PST-6-3, AR03-01, AR03-04, AR03-14, AR03-25, AR03-33, AR97-01sp2, AR90-01sp1, AR00-00sp1, AR00-05sp1, LA0416, 01-69, and AR05-IIA-1.

b $\mathrm{P}$ is PstI primer (5'CTCGTAGACTGCGTACATGCAG) and $\mathrm{M}$ is $M s e \mathrm{I}$ primer (5'GACGATGAGTCCTGAGTAA) followed by two selective base pairs according to Justesen et al. (12). Bold font denotes primer combinations selected for analysis of 27 additional isolates and 58 additional hierarchical-sampled isolates. 
clustered together, all isolates virulent on $\operatorname{Yr} 8$ and $\operatorname{Yr} 9$ clustered together, and isolate PST-21 was alone. Cluster analysis produced the same three groups with data generated from 9 primer pairs using 101 isolates (Fig. 2). In both data sets, similarity within groups was very high compared to similarity among groups.

In agreement with cluster analysis, the genetic differentiation as determined by Gst was high across populations $(\mathrm{Gst}=0.9363)$ but low within the new $(\mathrm{Gst}=0.0539)$ and old $(\mathrm{Gst}=0.1154)$ populations.

Because of limited DNA and poor amplification, data from only 17 primer combinations could be generated for four $P$. striiformis f. sp. tritici isolates from Denmark. However, each isolate clustered with United States isolates in the old group (avirulent to $\operatorname{Yr} 8$ and $Y r 9$ ) (data not shown).

TABLE 3. Origin, race, and virulence phenotype of the 59 Puccinia striiformis $\mathrm{f}$. sp. tritici isolates analyzed for the heirarchical sampling study in Arkansas, $2005^{\mathrm{a}}$

\begin{tabular}{|c|c|c|c|c|c|}
\hline Isolate & Arkansas region & Field & Source & Race $^{b}$ & Virulence phenotype $^{c}$ \\
\hline AR05-IA-1 & NW & 1 & Plant 1 & 100 & $1,3,8,9,10,11,12,16,17,18,19,20$ \\
\hline AR05-IA-3 & NW & 1 & Plant 1 & 100 & $1,3,8,9,10,11,12,16,17,18,19,20$ \\
\hline AR05-IA-5 & NW & 1 & Plant 1 & 99 & $1,3,9,10,11,12,16,17,18,19,20$ \\
\hline AR05-IA-9 & NW & 1 & Plant 1 & 100 & $1,3,8,9,10,11,12,16,17,18,19,20$ \\
\hline AR05-IIA-1 & NW & 1 & Hot spot 1 & 100 & $1,3,8,9,10,11,12,16,17,18,19,20$ \\
\hline AR05-IIA-3 & NW & 1 & Hot spot 1 & 100 & $1,3,8,9,10,11,12,16,17,18,19,20$ \\
\hline AR05-IIA-4 & NW & 1 & Hot spot 1 & 100 & $1,3,8,9,10,11,12,16,17,18,19,20$ \\
\hline AR05-IIIA-1 & NW & 1 & Transect 1 & 100 & $1,3,8,9,10,11,12,16,17,18,19,20$ \\
\hline AR05-IIIA-3 & NW & 1 & Transect 1 & 100 & $1,3,8,9,10,11,12,16,17,18,19,20$ \\
\hline AR05-IIIA-4 & NW & 1 & Transect 1 & 98 & $1,3,8,10,11,12,16,17,18,19,20$ \\
\hline AR05-IIIA-5 & NW & 1 & Transect 1 & 98 & $1,3,8,10,11,12,16,17,18,19,20$ \\
\hline AR05-IB-1 & NW & 2 & Plant 1 & 98 & $1,3,8,10,11,12,16,17,18,19,20$ \\
\hline AR05-IB-3 & NW & 2 & Plant 1 & 98 & $1,3,8,10,11,12,16,17,18,19,20$ \\
\hline AR05-IIB-1 & NW & 2 & Hot spot 1 & 97 & $1,3,10,11,12,16,17,18,19,20$ \\
\hline AR05-IC-9 & SW & 1 & Plant 1 & 98 & $1,3,8,10,11,12,16,17,18,19,20$ \\
\hline AR05-IIC-1 & SW & 1 & Hot spot 1 & 100 & $1,3,8,9,10,11,12,16,17,18,19,20$ \\
\hline AR05-IIC-3 & SW & 1 & Hot spot 1 & 100 & $1,3,8,9,10,11,12,16,17,18,19,20$ \\
\hline AR05-IIC-5 & SW & 1 & Hot spot 1 & 98 & $1,3,8,10,11,12,16,17,18,19,20$ \\
\hline AR05-IIC-7 & SW & 1 & Hot spot 1 & 100 & $1,3,8,9,10,11,12,16,17,18,19,20$ \\
\hline AR05-IIC-9 & SW & 1 & Hot spot 1 & 100 & $1,3,8,9,10,11,12,16,17,18,19,20$ \\
\hline AR05-IIID-1 & SW & 1 & Transect 1 & 100 & $1,3,8,9,10,11,12,16,17,18,19,20$ \\
\hline AR05-IIID-3 & SW & 1 & Transect 1 & 98 & $1,3,8,10,11,12,16,17,18,19,20$ \\
\hline AR05-IIID-5 & SW & 1 & Transect 1 & 100 & $1,3,8,9,10,11,12,16,17,18,19,20$ \\
\hline AR05-IIID-7 & SW & 1 & Transect 1 & 100 & $1,3,8,9,10,11,12,16,17,18,19,20$ \\
\hline AR05-IIID-9 & SW & 1 & Transect 1 & 100 & $1,3,8,9,10,11,12,16,17,18,19,20$ \\
\hline AR05-IE-1 & SW & 2 & Plant 1 & 100 & $1,3,8,9,10,11,12,16,17,18,19,20$ \\
\hline AR05-IE-3 & SW & 2 & Plant 1 & 98 & $1,3,8,10,11,12,16,17,18,19,20$ \\
\hline AR05-IIG-5 & $\mathrm{NE}$ & 1 & Hot spot 1 & 100 & $1,3,8,9,10,11,12,16,17,18,19,20$ \\
\hline AR05-IIG-7 & $\mathrm{NE}$ & 1 & Hot spot 1 & 98 & $1,3,8,10,11,12,16,17,18,19,20$ \\
\hline AR05-IIG-10 & $\mathrm{NE}$ & 1 & Hot spot 1 & 97 & $1,3,10,11,12,16,17,18,19,20$ \\
\hline AR05-IIIG-1 & $\mathrm{NE}$ & 1 & Transect 1 & 100 & $1,3,8,9,10,11,12,16,17,18,19,20$ \\
\hline AR05-IIIG-2 & NE & 1 & Transect 1 & 98 & $1,3,8,10,11,12,16,17,18,19,20$ \\
\hline AR05-IIIG-3 & $\mathrm{NE}$ & 1 & Transect 1 & 100 & $1,3,8,9,10,11,12,16,17,18,19,20$ \\
\hline AR05-IIIG-4 & $\mathrm{NE}$ & 1 & Transect 1 & 100 & $1,3,8,9,10,11,12,16,17,18,19,20$ \\
\hline AR05-IIIG-5 & $\mathrm{NE}$ & 1 & Transect 1 & 100 & $1,3,8,9,10,11,12,16,17,18,19,20$ \\
\hline AR05-IJ-1 & $\mathrm{NE}$ & 2 & Plant 1 & 100 & $1,3,8,9,10,11,12,16,17,18,19,20$ \\
\hline AR05-IJ-3 & $\mathrm{NE}$ & 2 & Plant 1 & 100 & $1,3,8,9,10,11,12,16,17,18,19,20$ \\
\hline AR05-IIJ-1 & $\mathrm{NE}$ & 2 & Hot spot 1 & 100 & $1,3,8,9,10,11,12,16,17,18,19,20$ \\
\hline AR05-IIJ-3 & $\mathrm{NE}$ & 2 & Hot spot 1 & 100 & $1,3,8,9,10,11,12,16,17,18,19,20$ \\
\hline AR05-IIK-1 & $\mathrm{NE}$ & 2 & Hot spot 2 & 98 & $1,3,8,10,11,12,16,17,18,19,20$ \\
\hline AR05-IIK-3 & $\mathrm{NE}$ & 2 & Hot spot 2 & 99 & $1,3,9,10,11,12,16,17,18,19,20$ \\
\hline
\end{tabular}

${ }^{a}$ In addition to virulence analysis, amplified fragment length polymorphism (AFLP) analysis was done and all isolates clustered into 'new' group (Figs. 1 and 2).

${ }^{\mathrm{b}}$ Race was identified according to Chen et al. (6).

${ }^{\mathrm{c}}$ Host differentials with a virulent (infection type 5 to 9) reaction to isolate are listed. Differential number, name, and (genes): $1=\mathrm{Lemhi}(\mathrm{Yr} 21), 2=\mathrm{Chinese} 166$ $(Y r 1), 3=$ Heines VII $(Y r 2, Y r H V I I), 4=$ Moro $(Y r 10, Y r M o r), 5=$ Paha $(Y r P a 1, Y r P a 2, Y r P a 3), 6=$ Druchamp $(Y r 3 a, Y r D r u 1, Y r D r u 2), 7=$ Yr5/6*AVS $(Y r 5)$, 8 = Produra $(Y r P r 1, Y r P r 2), 9=$ Yamhill $(Y r 2, Y r 4 a, Y r Y a m), 10=$ Stephens $(Y r 3 a, Y r S t e 1, Y r S t e 2), 11=$ Lee $(Y r 7, Y r 22, Y r 23), 12=$ Fielder $(Y r 6, Y r 20), 13=$

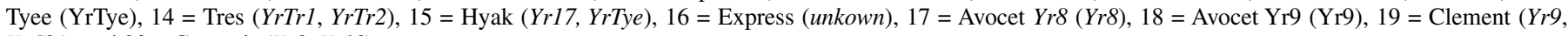
$\mathrm{YrCle})$, and $20=$ Compair $(\mathrm{Yr} 8, \mathrm{Yr} 19)$. 
Hierarchical sampling. In cladograms, all hierarchically sampled isolates (Table 2) grouped with isolates virulent on resistance genes $\operatorname{Yr} 8$ and $\operatorname{Yr} 9$ (Fig. 2). Little diversity among isolates was observed.
Of the 59 hierarchically-sampled isolates in 2005, four races (PST-97, PST-98, PST-99, and PST-100) were identified, and in some cases multiple races were recovered from the same plant, hotspot, and transect (Table 2). However, race differences were

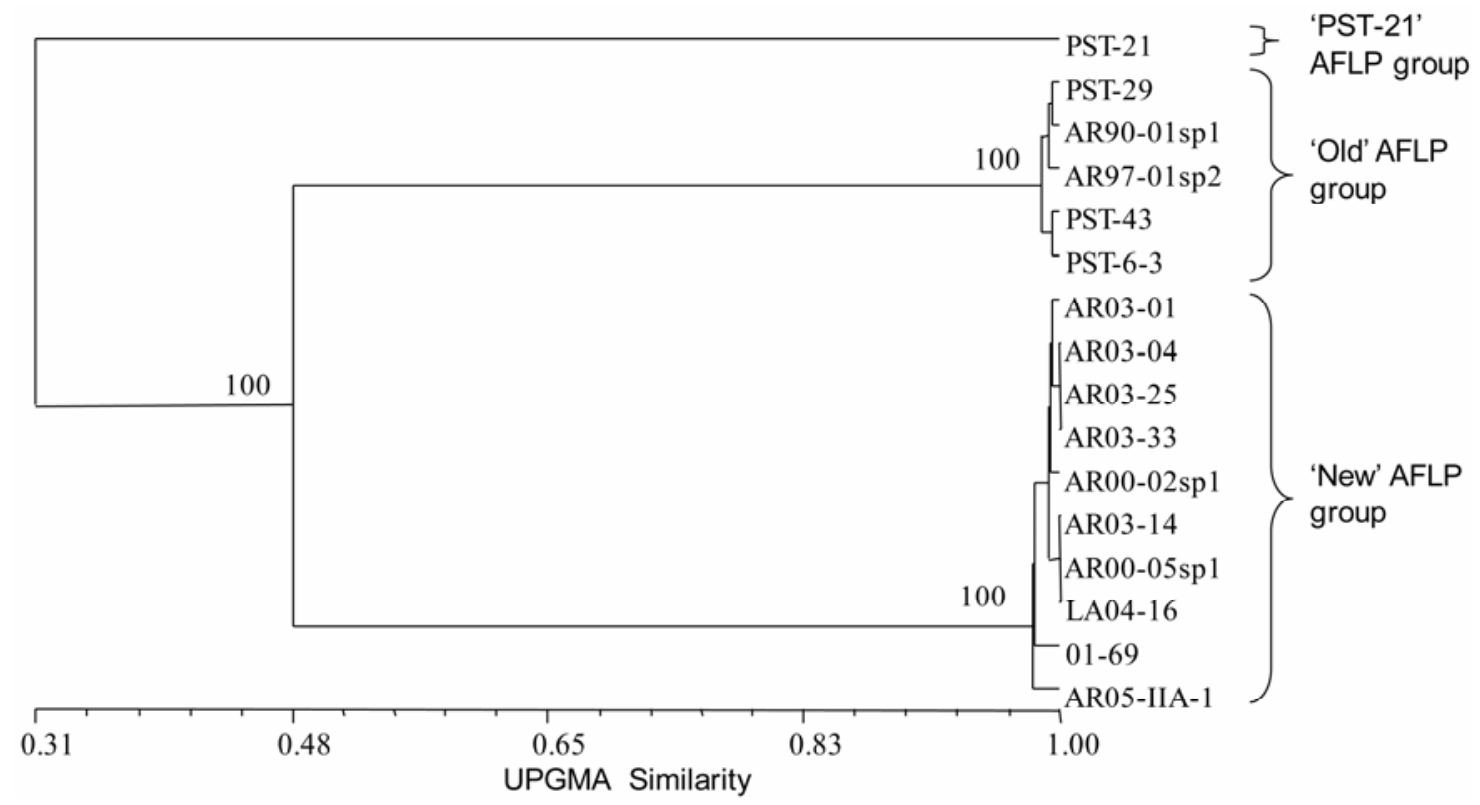

Fig. 1. Unweighted pair group method with arithmetic mean (UPGMA) dendogram showing similarity among 16 Puccinia striiformis f. sp. tritici isolates. Polymorphic markers from 22 amplified restriction length polymorphism (AFLP) primer combinations were used. Bootstrap values shown at branch points are based on 2,000 iterations.

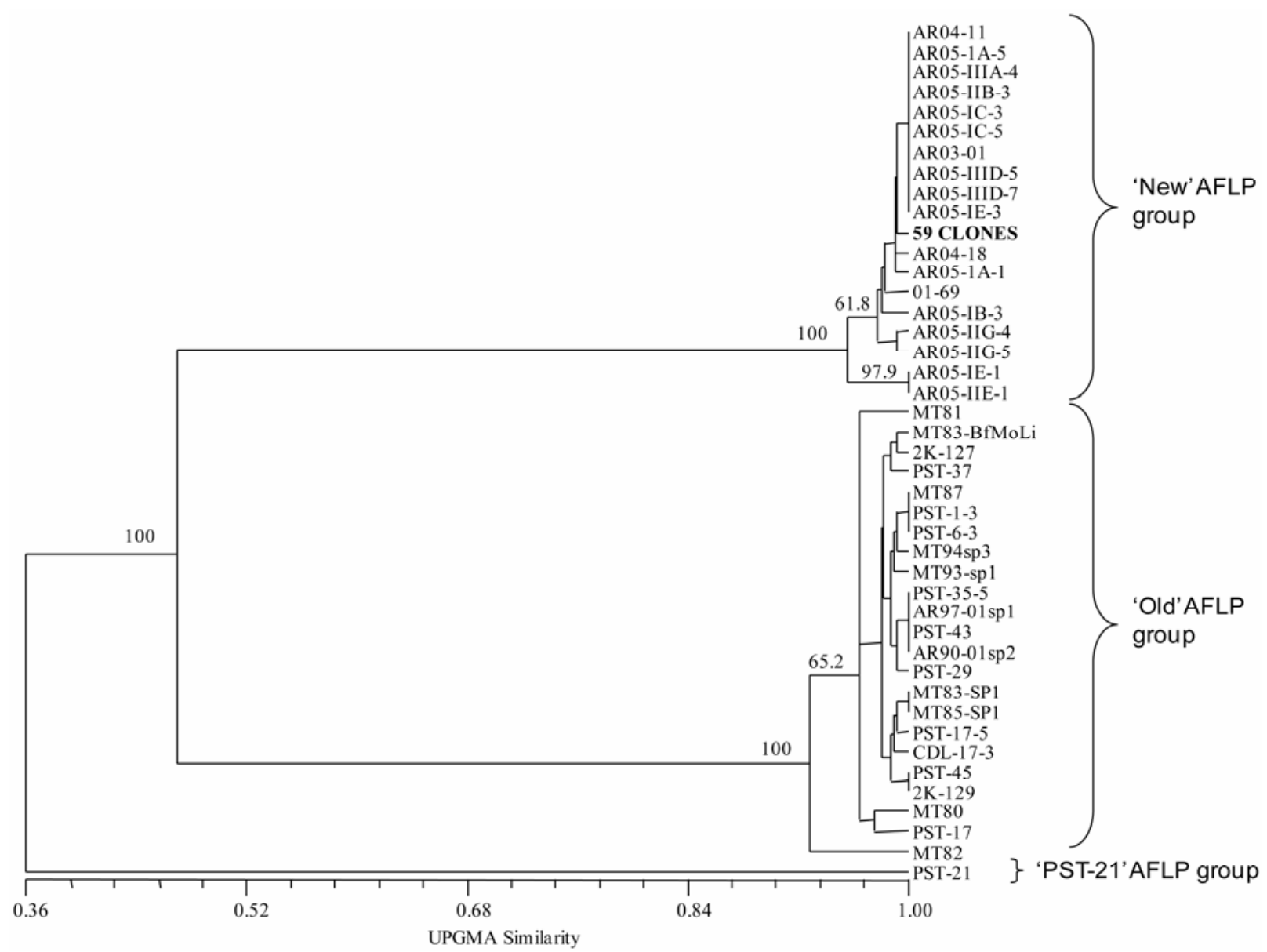

Fig. 2. Unweighted pair group method with arithmetic mean (UPGMA) dendogram showing similarity among 101 Puccinia striiformis f. sp. tritici isolates. Polymorphic markers from nine amplified restriction length polymorphism (AFLP) primer combinations were used. Bootstrap values shown at branch points are based on 2,000 iterations. Bold font denotes placement of 59 clonal isolates. 
due to differences in virulence only on Produra, Yamhill, and Stephens and infection types on these cultivars were frequently intermediate (i.e., neither highly virulent of highly avirulent). Additionally, discrepancies in infection type between replications of the same isolate on these differentials were found (i.e., infection type on one replicate 0 to 4 and considered avirulent, infection type on the other replicate 5 to 9 and considered virulent). No discrepancy between replicates occurred on any other differentials (data not shown).

\section{DISCUSSION}

The results of this study demonstrated that the contemporary population of $P$. striiformis f. sp. tritici in eastern United States since 2000 was genetically distinct from the population before 2000. The new population could be distinguished from the old population with all AFLP primer-pair combinations used in this study. Excluding polymorphisms specific to PST-21, over $90 \%$ of the polymorphisms found in this study separated isolates into the new or old population. Furthermore, the similarity among isolates within the old or new groups was at least six times greater than the similarity between groups. Therefore, the data indicate that it is unlikely that the new population of $P$. striiformis $\mathrm{f}$. sp. tritici in the United States originated from mutations in the older population.

The molecular differences among the new population, the old population, and the unique isolate PST-21 parallel significant biological differences between the three groups. Without exception, all examined isolates of the new population were virulent on resistance genes $\operatorname{Yr} 8$ and $\operatorname{Yr} 9$, whereas all isolates of the old population were avirulent on these two genes. Isolate PST-21 was only virulent on a single differential, Chinese 166. Except for isolates PST-21 and PST-1-3, all other isolates were avirulent on Chinese 166. With exception of two isolates 2K-127 (race PST-60) and 2K-129 (race PST-59) all isolates of the old population used in this study were avirulent on Express.

The origin of the new population could be explained by several hypotheses. One hypothesis is that the unique genotypes now present in the contemporary population existed at a low level and were not detected by the annual surveys that are conducted. However, Milus et al. (20) demonstrated that representative isolates within the new population were more aggressive and better adapted to warmer temperatures than representative isolates in the old population, making this hypothesis unlikely. Another hypothesis is that the old population in the United States is the progenitor of the new population. Based on virulence information, Chen (3) hypothesized that several races (including PST-59), which are virulent on Express but avirulent on $\operatorname{Yr} 8$ and $\operatorname{Yr} 9$, may be the progenitors of the new United States population. Although we only included one isolate of race PST-59 (isolate 2K-129), AFLP analysis clustered it into the old group. The evidence presented in the current study suggests a third hypothesis, namely that the new population arose from an exotic introduction. When nine AFLP primer pair combinations were used to examine isolates, the old and new populations could be distinguished by 110 polymorphic markers, while differences within the old and new populations could be distinguished by only nine and four markers, respectively. The high number of molecular differences between populations is not in line with a stepwise mutation. Stepwise mutation best explained the diversity in the $P$. striiformis f. sp. tritici population in Australia between 1979 and 1991 (24), in which no polymorphic AFLP or RAPD markers could be found within the Australian population, despite identification of many polymorphic markers between Australian isolates and isolates from Europe and South America. In addition to molecular differences, changes in virulence indicate an introduction may best explain that origin of the new population. In the eastern United States, the new population was virulent on $\operatorname{Yr} 8$ and $\operatorname{Yr} 9$, but also lacked virulence for the unknown resistance in the cultivars Agripro Mason and AR850 (E. A. Milus, unpublished data).

Inter-regional and international spread of the pathogen has been documented in China (30) and Europe (10), respectively, and introductions of $P$. striiformis have occurred in other regions of the world. P. striiformis f. sp. hordei was first found in South America near Bogota, Colombia in 1975 and by 1982 had affected nearly all the barley growing regions in South America (7). Barley stripe rust was first reported in the United States in 1991 (18) and is now the most important disease of barley in the western United States (16). P. striiformis f. sp. tritici was first reported in South Africa in 1996, and has remained a problem in that country to date (2). P. striiformis f. sp. tritici was first introduced to eastern Australia in $1979(28,29)$ and subsequently to New Zealand the following year (1). In 2002, P. striiformis f. sp. tritici was detected in Western Australia for the first time. Unlike the $P$. striiformis f. sp. tritici population observed in eastern Australia, isolates in Western Australia were virulent on resistance genes $\operatorname{Yr} 8$ and $\operatorname{Yr} 9$ (Australian nomenclature race $134 \mathrm{E} 16 \mathrm{~A}+$ ). Due to virulence on $\operatorname{Yr} 8$ and $\operatorname{Yr} 9$, and lack of virulence on $Y r 2$, $\mathrm{Yr} 3$, and $\mathrm{Yr} 4$, the P. striiformis f. sp. tritici population in Western Australia is believed to have been introduced from outside of the continent (27). This newly introduced population spread to Eastern Australia within a year and largely replaced the previous population.

The results of this study indicated that the new population rapidly became predominant in the eastern United States since 2000. All randomly collected isolates between 2000 and 2004 except for $2 \mathrm{~K}-127$ and $2 \mathrm{~K}-129$, and all hierarchical sampled isolates in 2005 , belonged to the new population. Additional evidence suggesting the new population is predominant includes data from annual race surveys conducted by the United States Department of Agriculture (USDA), and Agricultural Research Service (ARS) in Pullman, WA (X. M. Chen, personal communication). Of 662 isolates collected east of the Rocky Mountains during annual race surveys between 2001 and 2005, only isolates 01119-10 from Kansas in 2001 (PST-58), 01-224 from Nebraska in 2001 (PST-58), 01-066 from Louisiana in 2001 (PST-62), 02-23610 from Louisiana in 2002 (PST-55), and 04-017 from Texas in 2004 (PST-20), were avirulent on $\operatorname{Yr} 8$ or $\operatorname{Yr} 9$ (X. M. Chen, personal communication). Additionally, stripe rust has not been found since before 2000 on the cultivar Agripro Mason and breeding line AR850, which are susceptible to races of the old population but resistant to the new population (E. A. Milus, unpublished data).

Nearly $50 \%$ of the polymorphic markers identified in this study were specific to PST-21. The race PST-21 was first recovered from triticale in 1978 in California and is rarely found. PST-21 is distinct in that it grows slowly and with limited sporulation on wheat, and is a poor competitor in a race mixture (16).

The results of this study demonstrated that the new $P$. striiformis f. sp. tritici population was likely a result of an introduction, and it has displaced the old population in the eastern United States. The ability of this population to cause high yield-losses consistently, in areas where the majority of United States wheat is grown, is of great concern. Screening for and identifying available sources of resistance, investigation of the inheritance of resistance, and incorporation of diverse resistance into soft red winter wheat and hard red winter wheat lines grown in this region will be an important component of control for the foreseeable future.

\section{ACKNOWLEDGMENTS}

This work was supported in part by grants from the University of Arkansas agricultural experiment station and the Arkansas wheat promotion board. We thank X. Chen at the USDA-ARS in Pullman, WA, for isolates, seed of differential lines, survey data, and technical advice; A. Fejer Justesen at the Danish Institute of Agricultural Sciences in Flaakeb- 
jerg for technical advice; M. Johnston at Montana State University for isolates; J. Correll, K. Korth, and B. Okimoto at the University of Arkansas for technical support; C. Doetkott at North Dakota State University for statistical analysis; and anonymous reviewers for helpful feedback.

\section{LITERATURE CITED}

1. Beresford, R. M. 1982. Stripe rust (Puccinia striiformis) a new disease of wheat in New Zealand. Cereal Rust Bull. 10:35-41.

2. Boshoff, W. H. P., Pretorius, Z. A., and van Niekerk, B. D. 2002. Establishment, distribution, and pathogenicity of Puccinia striiformis $\mathrm{f}$. sp. tritici in South Africa. Plant Dis. 86:485-492.

3. Chen, X. M. 2005. Epidemiology and control of stripe rust [Puccinia striiformis f. sp. tritici] on wheat. Can. J. Plant Pathol. 27:314-337.

4. Chen, X. M., Line, R. F., and Leung, H. 1993. Relationship between virulence variation and DNA polymorphism in Puccinia striiformis. Phytopathology 83:1489-1497.

5. Chen, X., Line, R. F., and Leung, H. 1995. Virulence and polymorphic DNA relationships of Puccinia striiformis f. sp. hordei to other rusts. Phytopathology 85:1335-1342.

6. Chen, X. M., Moore, M., Milus, E. A., Long, D. L., Line, R. F., Marshall, D., and Jackson, L. 2002. Wheat stripe rust epidemics and races of Puccinia striiformis f. sp. tritici in the United States in 2000. Plant Dis. 86:39-46.

7. Dubin, H. J., and Stubbs, R. W. 1986. Epidemic spread of barley stripe rust in South America. Plant Dis. 70:141-144.

8. Enjalbert, J., Duan, X., Giraud, T., Vautrin, D., De Vallavieille-Pope, C., and Solignac, M. 2002. Isolation of twelve microsattelite loci, using an enrichment protocol, in the phytopathogenic fungus Puccinia striiformis f. sp. tritici. Mol. Ecol. Notes 2:563-565.

9. Enjalbert, J., Duan, X., Leconte, M., Hovmoller, M. S., and De Vallavieille-Pope, C. 2005. Genetic evidence of local adaptation of wheat yellow rust (Puccinia striiformis f. sp. tritici) within France. Mol. Ecol. 14:2065-2073.

10. Hovmoller, M. S., Justesen, A. F., and Brown, J. K. M. 2002. Clonality and long-distance migration of Puccinia striiformis f. sp. tritici in northwest Europe. Plant Pathol. 51:24-32.

11. Irish, B. M. 2004. New races of the downy mildew pathogen of spinach, identification of molecular markers for disease resistance, and molecular diversity of spinach germplasm. Ph.D. dissertation, University of Arkansas.

12. Justesen, A. F., Ridout, C. J., and Hovmoller, M. S. 2002. The recent history of Puccinia striiformis f. sp. tritici in Denmark as revealed by disease incidence and AFLP markers. Plant Pathol. 51:13-23.

13. Keller, S. M., McDermott, J. M., Pettway, R. E., Wolfe, M. S., and McDonald, B. A. 1997. Gene flow and sexual reproduction in the wheat glume blotch pathogen Phaeosphaeria nodorum (Anamorph Stagonospora nodorum). Phytopathology 87:353-358.

14. Linde, C., Zhan, J., and McDonald, B. A. 2002. Population structure of Mycosphaerella graminicola: From lesions to continents. Phytopathology 92:946-955.
15. Line, R. F. 2002. Stripe rust of wheat and barley in North America: A retrospective historical review. Annu. Rev. Phytopathol. 40:75-118.

16. Line, R. F., and Qayoum, A. 1991. Virulence, aggressiveness, evolution, and distribution of races of Puccinia striiformis (the cause of stripe rust of wheat) in North America. 1968-87. USDA-ARS Tech. Bull. 1788.

17. Lowe, A., Harris, S., and Ashton, P. 2004. Genetics: Design, Analysis, and Application. Blackwell Publishing, Malden, MA.

18. Marshall, D., and Sutton, R. L. 1995. Epidemiology of stripe rust, virulence of Puccinia striiformis f. sp. tritici, and yield loss in barley. Plant Dis. 79:732-737.

19. McDonald, B. A., Zhan, J., and Burdon, J. J. 1999. Genetic structure of Rhynchosporium secalis in Australia. Phytopathology 89:639-645.

20. Milus, E. A., Seyran, E., and McNew, R. 2006. Aggressiveness of Puccinia stiiformis f. sp. tritici isolates in the south-central United States. Plant Dis. 90:847-852.

21. Murray, M. G., and Thompson, W. F. 1980. Rapid isolation of highmolecular-weight plant DNA. Nucleic Acids Res. 8:4321-4325.

22. Peever, T. L., Zeigler, R. S., Dorrance, A. E., Correa-Victoria, F. J., and St. Martin, S. 2000. Pathogen population genetics and breeding for disease resistance. Published online. APSnet Feature, American Phytopathological Society, St. Paul, MN. http://www.apsnet.org/online/ feature/PathPopGenetics

23. Shan, W. X., Chen, S. Y., Kang, Z. S., Wu, L. R., and Li, Z. Q. 1998. Genetic diversity in Puccinia striiformis Westend. f. sp. tritici revealed by pathogen genome-specific repetitive sequence. Can. J. Bot. 76:587595.

24. Steele, K. A., Humphreys, E., Wellings, C. R., and Dickinson, M. J. 2001. Support for a stepwise mutation model for pathogen evolution in Australasian Puccinia striiformis f. sp. tritici by use of molecular markers. Plant Pathol. 50:174-180.

25. Villareal, L., Lannou, C., De Vallavieille-Pope, C., and Neema, C. 2002. Genetic variability in Puccinia striiformis f.sp. tritici populations sampled on a local scale during natural epidemics. Appl. Environ. Microbiol. 68:6138-6145.

26. Vos, P., Hogers, R., Bleeker, M., Reijans, M., van de Lee, T., Hornes, M., Frijters, A., Pot, J., Peleman, J., Kuiper, M., and Zabeau, M. 1995. AFLP: A new technique for DNA fingerprinting. Nucleic Acids Res. 23:44074414.

27. Wellings, C. R., and Kandal, K. R. 2004. Pathogen dynamics asscociated with historic stripe (yellow) rust epidemics in Australia in 2002 and 2003. Page A2.74 in: Proc. 11th Int. Cereal Rusts and Powdery Mildews Conf. John Innes Centre, Norwich, UK. European and Mediterranean Cereal Rust Foundation, Wageningen, Netherlands.

28. Wellings, C. R., and McIntosh, R. A. 1990. Puccinia striiformis f. sp. tritici in Australasia: Pathogenic changes during the first 10 years. Plant Pathol. 39:316-325.

29. Wellings, C. R., McIntosh, R. A., and Walker, J. 1987. Puccinia striiformis f. sp. tritici in Eastern Australia-possible means of entry and implication for plant quarantine. Plant Pathol. 36:239-241.

30. Zeng, S.-M., and Lou, Y. 2006. Long-distance spread and interregional epidemics of wheat stripe rust in China. Plant Dis. 90:980-988. 